JSAP: Journal Syariah and Accounting Public

ISSN: 2622-3538

Available Online at https://journal.umgo.ac.id/index.php/JSAP/index

Vol. 4, No. 2 Desember 2021

DOI: $10.31314 /$ jsap.4.2.77-88.2021

\title{
ANALISIS TRANSPARANSI DAN AKUNTABILITAS PENGELOLAAN KEUANGAN DESA OMBULO TANGO KECAMATAN TOLANGOHULA
}

Fitria Melynsyah Yusuf ${ }^{1}$, Yuwin $\mathrm{Ali}^{2}{ }^{2}$ Sariyanti P. Bouti ${ }^{3}$

1.2.3, Program Studi Akuntansi, Universitas Muhammadiyah Gorontalo, Indonesia

Email; fitriayusuf@umgo.ac.id, yuwinali@umgo.ac.id

Info Artikel: Diterima: 22 November 2021, Disetujui: 24 Sesembar 2021, Publish 29 Desember 2021

\begin{abstract}
:
This study aims to analyze the transparency and accountability of financial management in Ombulo Tango village, Tolangohula sub-district. This study uses a descriptive type of research with a qualitative approach, with financial management indikator form mardiasmo. The results of this study are the village government has implemented good management but has not been optimal, It is good because the village government has made periodic reports, complete with supporting documents for reporting to the district government, The results are less than optimal because the report is only made for the district government while the community does not yet have easy participation and access in terms of regional financial management. The community also complains that there is no information board that can be seen directly which is a form of accountability to the community.
\end{abstract}

Keywords: Transparency, Accountability, Financial Management

\begin{abstract}
Abstrak:
Penelitian ini bertujuan untuk menganalisis transparansi dan akuntabilitas pengelolaan keuangan desa Ombulo Tango kecamatan tolangohula. Penelitian ini menggunakan jenis penelitian deksriptif dengan pendekatan kualitatif, dengan indikator penelitian pengelolaan keuangan dari Mardiasmo. Hasil penelitian ini adalah pemerintah desa sudah melaksanakan pengelolaan dengan baik namun belum maksimal, Baiknya karena pemerintah desa sudah membuat laporan secara berkala, lengkap dengan dokumen-dokumen pendukung untuk pelaporan kepada pemerintah kabupaten, Hasil kurang maksimalnya karena laporan tersebut hanya dibuat untuk pemerintah kabupaten saja sedangkan masyarakat belum memiliki partisipasi dan akses yang mudah dalam hal pengelolaan keuangan daerah. Masyarakat juga mengeluhkan belum adanya papan informasi yang dapat dilihat secara langsung yang merupakan bentuk pertanggungjawaban kepada masyarakat.
\end{abstract}

Kata kunci : Tranparansi, Akuntabilitas, Pengelolaan Keuangan

\section{PENDAHULUAN}

Dalam rangka penyelenggaraan pemerintahan maka Negara Kesatuan Republik Indonesia (NKRI) dibagi atas daerah-daerah provinsi, provinsi dibagi atas daerah-daerah kabupaten/kota. Tiap-tiap daerah tersebut mempunyai hak mengatur rumah tangganya sendiri sebagaimana disebut dengan otonomi daerah, hal ini dilaksanakan oleh pemerintah pusat sebagai upaya untuk meningkatkan efisiensi dan efektivitas penyelenggaraan pemerintahan 
dan pelayanan kepada masyarakat secara langsung.

Untuk mendukung pelaksanaan otonomi daerah maka pemerintah membentuk Undang-Undang No 6 Tahun 2014 tentang Penyelenggaraan pemerintahan desa, Undang-Undang inilah yang menjadi dasar penguat status daerah/desa sebagai lembaga pemerintahan dan diharapkan dapat memajukan..masyarakat..untuk dapat bisa memberdayakan masyarakat didesa. Desa sendiri juga sebagai pemerintahan yang terkecil juga harus melakukan pembaharuan guna untuk mendukung program pemerintah pusat yakni terciptanya pemerintahan yang pemerintahannya bertanggungjawab dan sejalan dengan prinsip demokrasi, desa juga diharapkan mampu untuk meningkatkan kehidupan masyarakat desa. Kemajuan pembangunan desa ini tidak kalah pentingnya dimana pembangunan pada daerah desa juga memerlukan adanya perencanaan, pelaksanaan yang baik serta dapat dipertanggungjawaban.

Pelaksanaan pembangunan di desa harus sesuai dengan apa yang telah direncanakan dalam proses perencanaan dan masyarakat berhak untuk dapat mengetahui dan juga melakukan pengawasan terhadap kegiatan pembangunan yang didesa. Mardiasmo (2009) juga menyebutkan bahwa ada tiga prinsip utama yang penting untuk mendasari pengelolaan keuangan daerah yakni, akuntabilitas, transparansi dan value for money. Akuntanbilitas publik merupakan suatu kewajiban bagi pihak yang memegang amanah untuk bagi yang memberikan pertanggungjawaban mengungkapkan segala aktivitas yang dilakukan untuk dapat dipertanggungjawabkan kepada pihak yang memberikan amanah itu. Akuntabilitas diartikan sebagai suatu pertanggungjawaban dengan dapat untuk menciptakan suatu pengawasan melalui distribusi kekuasaan pada berbagai pihak/lembaga pemerintah sehingga bisa mengurangi setiap penumpukan kekuasaan dan sekaligus menciptakan kondisi saling mengawasi (check and balance system) menurut Krina (2012).

Transparansi adalah prinsip yang menjamin akses atau kebebasan bagi setiap orang untuk dapat memperoleh informasi tentang penyelenggaraan yang dilaksanakan oleh pemerintahan seperti tentang suatu kebijakan, proses pembuatan dan pelaksanaan program, dan hasil-hasil yang telah dicapai, transparansi sendiri memiliki 2 aspek yakni sebagai berikut; (1). Komunikasi publik oleh pemerintah, dan (2) hak masyarakat terhadap akses informasi (Krina,2012). Transparansi dibangun atas dasar arus informasi yang seluruh proses pemerintahan bebas, informasi perlu diakses oleh pihak-pihak yang memiliki kepentingan oleh karena itu informasi yang tersedia harus ini memadai agar dapat dimengerti dan dipantau (Corrynata,2015). 
Dalam penelitian yang dilakukan Yulianti (2019) menyatakan bahwa pengelolaan APBdesa sudah berjalan dengan cukup baik, hal ini dapat dilihat dengan adanya musyawarah yang dibuat desa sebagai tempat pertukaran informasi antara pemerintah desa dan masyarakat, dan juga pemerintah desa sudah menyediakan dokumen seperti APBDesa yang dapat dilihat oleh masyarakat yang berkeinginan untuk mengetahuinya, adapun kekurangan transparansi ini dalam hal pengelolaan APBDesa di Desa Teluk Beringin, yaitu kurang terbukanya informasi tentang anggaran atau pembiayaan yang diinformasikan serta proses dalam pelaksanaan melalui pembangunan ini desa kepada masyarakat. Selain itu pemerintah desa juga masih tidak menyediakan papan informasi untuk pengumuman desa sebagai bentuk transparansi yang dilakukan dalam bentuk pengelolaan APBDesa untuk masyarakat di Desa Teluk Beringin. Selanjutnya dalam penelitian Wahyu (2018) berpendapat bahwa dari segi transparansi untuk Desa Borong Pa'la'la sepenuhnya sudah hampir sesuai dengan Peraturan Menteri Dalam Negri Nomor 133 Tahun 2014 yakni adanya musrenbangdes setiap awal tahun untuk mengapresiasi ide atau keluhan dari warga masyarakat, selalu menginformasikan secara lisan, tertulis jumlah dana yang didapat dari pemerintah, serta adanya papan-papan informasi mengenai kegiatan setiap pembangunan yang akan atau sedang dikerjakan. Oleh sebab itu Desa Borong Pa'la'la dikatakan transparan.

Widiyanti dalam penelitiannya (2017) berpendapat bahwa dalam pelaporan keuangan Desa Sumberejo untuk semester pertama ini telah bisa terlaksana tepat waktu sesuai dengan aturan Permendagri No. 113 Tahun 2014, namun berbeda untuk pelaporan semester akhir tahun anggaran 2016 karena masih dalam periode berjalan belum bisa membuat keputusan hasil sesuai menurut Permendagri No. 113 Tahun 2014 sedangakan dari segi transparansi untuk Desa Sumberejo sesuai dengan aturan Permendagri No. 113 Tahun 2014 yakni adanya musrenbangdes setiap awal tahun untuk mengapresiasikan ide ataupun keluhan dari masyarakat setempat, serta selalu menginformasikan secara tertulis jumlah dana yang didapat dari pemerintah desa, serta adanya papan informasi kegiatan pembangunan yang sedang dikerjakan oleh pemerintah. Masyarakat sebagai pihak yang mendapatkan informasi, maka dalam konsep transparansi dan akuntabilitas hal yang paling penting ialah terkait keterbukaan dimana masyarakat diberi kemudahan untuk dapat mengakses segala informasi yang menjadi hak masyarakat. Hal sesuai dengan apa yang disebutkan pada aturan UndangUndang No. 14 Tahun 2008 tentang keterbukaan informasi publik dimana pada Bab 2 Pasal 2 Ayat 1 disebutkan bahwasannya setiap informasi publik bersifat 
terbuka dan dapat diakses oleh setiap pengguna informasi publik. Sesuai prinsip demokrasi kepala desa mempunyai kewajiban untuk dapat memberikan laporan penyelenggaraan pemerintahan desa untuk dilaporkan kepada bupati/walikota melalui camat satu kali dalam satu tahun, laporan pertanggungjawaban kepada BPD disampaikan satu kali saja dalam satu tahun dalam musyawarah BPD, dan rutin untuk menginformasikan laporan penyelenggaran pemerintah desa ini kepada masyarakat dapat berupa selembaran yang ditempelkan pada papan pengumuman, diinformasikan secara lisan dalam berbagai bentuk pertemuan masyarakat yang ada desa. Berdasarkan dari teori dan beberapa temuan yang telah dilakukan diatas peneliti menyimpulkan bahwa apa itu good governance akan tercipta apabila pemerintah daerah sudah menerapkan prinsip tranparansi dan akuntabilitas yang merupakan unsur penting dalam menjalankan pemerintahan dalam hal pengelolaan keuangan desa. Tujuan penelitian ini untuk dapat menganalisis bagaimana proses transparansi dan akuntabilitas pengelolaan keuangan dilingkungan yang ada didesa Ombulo Tango Kecamatan Tolangohula.

Faktanya berdasarkan observasi awal yang telah dilakukan oleh peneliti pada kantor Desa Ombulo sendiri, masih menemukan bahwa kurangnya proses transparansi dan akuntabilitas pemerintahan didesa Ombulo Tango, dalam hal transparansi pemerintah desa Ombulo Tango belum mampu mengoptimalkan media yang ada untuk digunakan sebagai bentuk fasilitas untuk memberikan informasi pengelolaan keuangan desa kepada masyarakat. Hal itu seperti belum maksimalnya sumber informasi berupa papan pengumuman ataupun papan-papan informasi mengenai anggaran penerimaan dan belanja desa, padahal masyarakat desa harus mengetahui juga dan ikut serta dalam mengawasi pengelolaan keuangan desa tetapi pada kenyataannya masih banyak masyarakat yang tidak dan belum mengetahui hal anggaran pendapatan yang diterima oleh pemerintah desa, dan hal ini juga dapat menimbulkan kurangnya rasa percaya masyarakat terhadap pemerintah desa dalam hal pengelolaan keuangan desa serta pemerintah desa tidak melibatkan masyarakat dalam proses untuk dapat melaksanakan kegiatan musrenbang desa yang membicarakan masalah dan potensi yang terjadi di desa tersebut. Selain itu prinsip akuntablitas belum sepenuhnya diterapkan oleh pemerintah desa Ombulo Tango sendir karena dalam hal ini pemerintah desa belum memahami tentang pengelolaan pembelanjaan desa dimana masih ada potongan pajak untuk pembelanjaan tersebut, contoh pembelanjaan desa yang dapat potongan pajak adalah honor/insentif, upah kerja, servis, ATK, pakaian dinas, alat kebersihan, 
makan minum, foto copy, computer, printer, kamera dan lain-lain, dalam hal ini juga pemerintah desa Ombulo Tango hanya melaporkan soal pertanggungjawaban kepihak inspektorat saja dan tidak melibatkan masyarakat.

Masyarakat tidak hanya memiliki hak untuk dapat mengetahui anggaran tersebut akan tetapi juga memiliki hak untuk menuntut pertanggungjawaban atas rencana ataupun pelaksanaan anggaran yang sudah dilaksanakan. Pemerintah daerah seharusnya perlu juga menyiapkan kebijakan yang jelas tentang cara mendapatkan informasi, kebijakan ini akan memperjelas bentuk informasi yang dapat diakses oleh masyarakat ataupun bentuk informasi yang bersifat rahasia, bagaimana cara mendapatkan informasi itu, lama waktu untuk mendapatkan informasi, serta prosedur pengaduan apabila informasi tersebut tidak / belum sampai kepada masyarakat. Pengelolaan keuangan ini desa tentunya harus dilakukan dengan manajemen yang baik dan akuntabel, Karena dana tersebut dalam jumlah yang banyak dan sangat besar.

\section{METODE PENELITIAN}

Jenis penelitian yang peneliti digunakan dalam penelitian ini yakni penelitian kualitatif. sumber data primer adalah data yang didapatkan melalui suatu kegiatan wawancara dengan subjek penelitian dan dengan melakukan observasi atau pengamatan secara langsung dilapangan dan juga bahwa data sekunder merupakan sumber data yang tidak langsung memberikan data kepada pengumpulan data.

\section{HASIL DAN PEMBAHASAN}

\section{Transparansi}

Berdasarkan keseluruhan dari hasil wawancara diatas maka itu peneliti dapat menganalisis, serta dapat menyimpulkan bahwa tingkat transparansi tentang pengelolaan keuangan desa belum sepenuhnya termasuk dalam prinsip transparansi yang dikemukakan oleh mardiasmo dimana anggota masyarakat juga memiliki hak dan akses yang sama untuk dapat mengetahui proses pengeloaan keuangan desa karena menyangkut hak dan aspirasi yang berhubungan dengan kepentingan masyarakat. Hal ini juga sangat jelas dalam wawancara yang dilakukan bahwa masyarakat pada umumnya tidak mengetahui adanya informasi jelas tentang pengelolaan keuangan desa. Teori transparansi keuangan dalam kerangka konseptual yang sesuai dengan standar akuntansi pemerintahan (2010) menyatakan bahwa pengertian transparansi ini adalah untuk memberikan informasi keuangan yang terbuka dan jujur kepada seluruh anggota masyarakat yang ada berdasarkan pertimbangan bahwa masyarakat juga memiliki hak untuk dapat mengetahui ini secara terbuka dan juga menyeluruh atas 
pertanggungjawaban yang dibuat oleh pemerintah dalam pengelolaan sumber daya yang dapat dipercaya menurut peraturan pada perudang-undangan. Pengertian lain dijelaskan oleh sukrisno agoes dan i cenik ardana (2009) yakni tranparansi berarti sebuah kewajiban bagi para pengelola untuk bisa menjalankan prinsip keterbukaan dalam proses keputusan penyampaian informasi.

Keterbukaan yang dimaksud dalam menyampaikan informasi juga harus lengkap, benar, dan tepat waktu kepada semua pemangku kepentingan. Tidak boleh ada hal-hal yang dirahasiakan, disembunyikan, ditutup-tutupi, atau ditunda untuk pengungkapanya kepada pihak yang lain. Transparansi merupakan salah satu aspek yang mendasar guna akan terwujudnya penyelenggaraan pemerintah yang baik, dan juga perwujudan tata pemerintahan yang baik dengan mensyaratkan adanya keterbukaan informasi, keterlibatan, dan juga kemudahan akses bagi setiap masyarakat terhadap proses penyelenggaraan pemerintah. (Hari Sabarno,2009). Keterbukaan dan kejujuran kepada masyarakat desa berdasarkan pertimbangan bahwa masyarakat juga memiliki hak untuk mengetahui secara terbuka dan menyeluruh atas setiap apa yang menjadi tanggungjawabnya dibuat oleh pemerintahan dalam sumber daya yang ada telah dipercayakan kepadanya dalam ketaatan pada aturan perundang-undangan (Abdul Hafiz, 2011). Pengelolaan keuangan ini desa tentunya harus dilakukan dengan manajemen yang baik dan akuntabel, Karena dana tersebut dalam jumlah yang banyak dan sangat besar maka dalam proses pengelolaannya harus transparan, tepat sasaran juga penggunaannya harus kebutuhan masyarakat.

Adapun dalam penelitian ini peneliti menggunakan indikator teori dari ahli mardiasmo (2009) guna untuk menganalisis proses jalanya transparansi pengelolaan keuangan didesa Ombulo Tango Kecamatan Tolangohula Kabupaten Gorontalo. Dalam teori ini ahli mardiasmo 2009 sudah menjelaskan bahwa dalam proses perencanaan, penyusunan, pelaksanaan pengelolaan anggaran daerah secara utuh. Transparansi sendiri dapat memberikan arti bahwa anggota masyarakat memiliki hak dan juga akses yang sama untuk mengetahui suatu proses anggaran karena ini menyangkut aspirasi dan kepentingan masyarakat, terutama dalam hal untuk dapat memenuhi kebutuhan-kebutuhan hidup banyak masyarakat. Sebagaimana menjadi fokus dalam penelitian diatas adalah bagaimana proses tranparansi dan akuntabilitas yang diterapkan oleh pemerintah daerah desa Ombulo Tango.

Oleh karena itu berdasarkan keseluruhan dari hasil wawancara dan observasi yang telah dilakukan oleh peneliti, peneliti menemukan bahwa didesa Ombulo Tango Kecamatan Tolangohula Kabupaten Gorontalo ini belum sesuai dengan prinsip 
transparansi menurut para ahli teori indikator oleh mardiasamo. Peneliti menyimpulkan ini karena dari hasil wawancara beberapa informan menyatakan bahwa adanya informasi dari pemerintah desa namun hanya melalui website saja, sedangkan beberapa masyarakat masih tidak mengerti akan hal tersebut, pemerintah daerah juga masih kurang untuk memaksimalkan kemudahan akses bagi masyarakat untuk bisa mengetahui pengelolaan keuangan desa yang dilakukan oleh pemerintah desa Ombulo Tango ini. Temuan lain yang ditemukan oleh peneliti juga memperoleh kesamaan yang ditemukan oleh Wiken yulianti dalam judul peneltiannya "Analisis Transparansi Dalam Pengelolaan Anggaran Pendapatan Dan Belanja Desa pada Desa Teluk Beringin Kecamatan Gunung Toar Kabupaten Kuantan Singingi" dari penelitian ini juga dapat menunjukkan bahwa transparansi dalam hal pengelolaan APBDesa di Desa Teluk Beringin Kecamatan Gunung Toar Kabupaten Kuantan Singingi sudah berjalan dengan cukup baik, hal ini dilihat dengan adanya musyawarah desa sebagai tempat pertukaran informasi antara pemerintah desa dan juga masyarakat, dan juga pemerintah desa yang menyediakan dokumen APBDesa untuk dapat dilihat oleh masyarakat yang ingin untuk bisa mengetahuinya. Adapun kekurangan transparansi dalam pengelolaan APBDesa di Desa Teluk Beringin, ialah kurang terbukanya informasi-informasi seperti tentang anggaran pembiayaan dalam hal pelaksanaan pembangunan yang didesa kepada masyarakat. Selain itu, pemerintah desa juga tidak dapat menyediakan papan informasi yakni pengumuman desa, sebagai bentuk transparansi dalam pengelolaan APBDesa untuk masyarakat di Desa Teluk Beringin. Adapun faktor yang mendukung dan penghambat dalam penelitian ini ialah faktor pendukung lain seperti aturan yang telah berlaku, ketepatan fungsi dan isu yang berkembang selama ini, sedangkan faktor lain yang menjadi penghambatnya lainya ialah kurangnya sosialisasi kepada rakyat, dan kurang profesionalisme (SDM) dan rendahnya partisipasi masyarakat.

\section{Akuntabilitas}

Dari hasil wawancara serta analisa yang dibuat oleh peneliti sebagaimana telah dijelaskan, maka dapat disimpulkan bahwa prinsip akuntabilitas menurut mardiasmo juga belum sepenuhnya diterapkan oleh pemerintah desa Ombulo Tango. Dimana prinsip akuntabilitas prinsip pertanggungjawaban publik yang berarti bahwa semua proses penganggaran yang dimulai dari perencanaan, penyusunan, dan pelaksanaan harus benar-benar dapat dilaporkan dan dipertanggung jawabkan dengan baik kepada para pemerintah kabupaten Gorontalo dan juga sampa kepada masyarakat. Faktanya dari hasil keseluruhan wawancara diatas masih ada yang belum mengetahui bentuk laporan 
pertanggungjawaban yang dibuat tersebut, memang pemerintah desa selalu membuat laporan secara berkala namun hanya disampaikan untuk pemerintah pusat saja sebagai tujuan, sedangkan untuk masyarakat sendiri hanya mengetahui akan adanya laporan secara berkala yang dibuat.

Standar Akuntansi Pemerintah menjelaskan bahwa transparansi adalah bentuk memberikan informasi keuangan yang terbuka dan jujur kepada masyarakat berdasarkan pertimbangan bahwa masyarakat memiliki hak untuk mengetahui secara terbuka dan menyeluruh atas pertanggungjawaban yang dibuat oleh pemerintah dalam pengelolaan sumber daya yang dipercayakan kepadanya dan ketaatannya kepada perundang-undangan.

Transparansi menjadi sangat penting bagi pelaksanaan fungsi-fungsi dalam pemerintahan untuk dapat menjalankan mandate dari rakyat. Mengingat pemerintah saat memiliki kewenangan mengambil berbagai keputusan penting yang berdampak bagi orang banyak, pemerintah harus bisa menyediakan informasi yang lengkap mengenai apa yang dikerjakannya.

Dengan demikian transparansi akan menjadi instrumen paling penting yang dapat menyelamatkan uang rakyat dari kemungkinan perbuatan korupsi. Menurut ahli Mardiasmo (2009), Akuntabilitas publik juga merupakan suatu kewajiban pihak pemegang amanah (agent) untuk memberikan pertanggungjawaban, menyajikan, melaporkan, dan mengungkapkan segala aktivitas dan kegiatan yang menjadi tanggungjawabnya kepada pihak pemberi amanah (principal) yang memiliki hak dan kewenangan untuk meminta pertanggungjawaban tersebut.

Akuntabilitas juga merupakan alat instrumen untuk kegiatan kontrol terutama dalam pencapaian hasil pada proses pelayanan publik oleh pemerintah. Dalam hubungan ini tentu diperlukan evaluasi kinerja yang dilakukan untuk mengetahui sejauh mana pencapaian hasil serta caracara yang digunakan untuk mencapai semua itu. Pengendalian sebagai bagian yang penting dalam manejemen yang baik adalah hal yang saling menunjang dengan akuntabilitas. Dengan kata lain pengendalian tidak dapat berjalan efisiensi dan efektif apabila tidak ditunjang dengan sistem mekanisme akuntabilitas yang baik dan juga sebaliknya (Nasirah,2016). Waluyo (2017) mendefinisikan akuntabilitas sebagai suatu keadaan yang dapat dipertanggungjawabkan, akuntabel juga memiliki arti kemampuan untuk dapat dipertanggungjawabkan oleh pemerintah dengan secara eksplisit, dan sesuatu yang bisa untuk dapat diperhitungkan atau dipertanggung jawabkan.

Adapun dalam penelitian ini peneliti ini menggunakan teori menurut mardiasmo (2009) untuk menganalisis proses akuntabilitas pengelolaan keuangan desa Ombulo Tango. Mardiasmo juga 
menjelaskan bahwa suatu akuntanbilitas publik merupakan kewajiban bagi pihak pemegang amanah untuk dapat memberikan suatu seperti bentuk pertanggungjawaban..mengungkapkan

segala aktivitas yang dilakukan dan dipertanggungjawabkan kepada pihak yang memberikan amanah. Akuntabilitas juga dapat diartikan sebagai bentuk kewajiban untuk bisa da dapat mempertanggungjawabkan suatu kegagalan atau keberhasilan dalam pelaksanaan misi organisasi dalam mencapai tujuan yang sudah direncanakan sebelumnya melalui suatu pertanggungjawaban yang dilaksanakan secara periodik.

Sebagaimana menjadi fokus penelitian yang telah digambarkan dari penelitian diatas di fokuskan pada bagaimana transparansi dan akuntabilitas pengelolaan keuangan desa Ombulo Tango Kecamatan Tolangohula. Akuntabilitas ini dapat juga diartikan sebagai kewajiban-kewajiban dari pihak individu atau perusahaan yang telah dipercayakan untuk bisa mengelola sumber daya publik, yang bersangkutan harus dapat menjawab hal-hal menyangkut tanggungjawab.

Menurut Halim (2014) akuntabilitas adalah suatu kewajiban untuk dapat dan bisa memberikan pertanggungjawaban atau menjawab atau menerangkan kinerja dan tindakan oleh seseorang atau badan hukum sah atau pimpinan suatu organisasi kepada pihak yang memiliki hak atau berkewenangan untuk dapat langsung mengakases suatu pertanggungjawaban. Suatu perusahaan dan atau organisasi dapat dikatakan akuntabiltas jika perusahaan atau organisasi tersebut mampu menyajikan informasi secara terbuka dalam pertanggungjawaban mengenai keputusan yang diambil, dan informasi yang bersifat rahasia, bagaimana caranya mendapatkan informasi itu, lama waktu untuk mendapatkan informasi tersebut, serta prosedur pengaduan apabila informasi tersebut tidak / belum sampai kepada masyarakat.

Sedangkan menurut Mahmudi (2010) akuntabilitas adalah suatu kewajiban agen (pemerintah) untuk dapat bisa mengelola sumber daya, melaporkan, serta mengungkapkan segala aktivitas dan kegiatan yang berhubungan dengan penggunaan sumber daya publik kepada pemberi mandat. Kemudian Seperti yang dikemukakan Mardiasmo (2009) yakni akuntabilitas merupakan satu prinsip pertanggungjawaban kepada publik terbuka yang berarti seluruh proses penganggaran mulai dari proses Penyusunan, perencanaan, pelaksanaan) harus benarbenar dilaporkan dan dapat dipercaya serta dipertanggunjawabkan kepada DPRD dan masyarakat. Menurut hasil observasi awal yang ditemui peneliti di kantor desa Ombulo Tango Kecamatan Tolangohula bahwa pemerintah desa masih kurang akuntabel dalam pengelolaan keuangan desa. 
Berdasarkan hasil wawancara dan analisis peneliti, maka peneliti menemukan bahwa didesa Ombulo Tango sendiri, dalam pengelolaan keuangan desa belum sepenuhnya menerapkan prinsip akuntablilitas ini dikarenakan masih ada masyarakat yang belum bisa tau mengenai laporan yang dipertanggungjawaban pemerintah desa terkait pengelolaan keuangan desa. Hal yang ditemui ini memiliki kesamaaan dengan peneliti terdahulu yang dilakukan oleh wiken yulianti bahwa dimana dalam hal pengelolaan keuangan pemerintah desa tidak memberikan informasi mengenai penggunaan anggaran serta pelaksanaan pembangunan desa. Hal ini tentunya tidak sejalan dengan prinsip akuntabilitas yang dikemukakan oleh ahli mardiasmo dimana yang dimaksud dalam prinsip akuntabilitas adalah prinsip-prinsip .pertanggungjawaban publik yang berarti bahwa segala proses untuk penganggaran mulai dari perencanaan, penyusunan, dan pelaksanaannya harus benar-benar dapat dilaporkan dan dipertanggung jawabkan kepada DPRD dan juga masyarakat. Hal ini juga sejalan dengan penelitian terdahulu .

Dari uraian diatas melalui observasi awal yang telah dilakukan dan keseluruhan hasil wawancara serta hasil analisis peneliti maka ini dapat disimpulkan bahwa prinsipprinsip akuntabilitas oleh pemerintah desa Ombulo Tango dalam hal pengelolaan keuangan desa sudah cukup baik karena pemerintah desa selalu berupaya membuat laporan pertanggungjawaban secara berkala namun masih ada masyarakat yang belum juga dapat mengetahui mengenai laporan pertanggungjawaban yang dibuat oleh pemerintah desa.

\section{KESIMPULAN}

Berdasarkan hasil pemabah-asan yang sudah ada diatas maka mengenai Analisis Transparansi dan Akuntabilitas Pengelolaan Keuangan Desa Ombulo Tango Kecamatan Tolangohula sendiri sudah bisa melaksanakan pengelolaan dengan baik hanya saja belum maksimal, hal Baiknya karena pemerintah desa sudah bisa membuat laporan dalam bentuk pertanggungjawaban secara berkala, lengkap dengan dokumen-dokumen pendukung untuk dijadikan bukti pelaporan kepada pemerintah kabupaten yang berkaitan, Hasil kurang maksimalnya karena laporan tersebut hanya dilaporkan untuk pemerintah kabupaten Gorontalo saja, sedangkan masyarakat belum memiliki partisipasi dan akses yang mudah dalam hal pengelolaan keuangan daerah. Masyarakat juga mengeluhkan belum adanya papan informasi yang dapat dilihat secara langsung yang merupakan bentuk pertanggungjawaban kepada masyarakat, maka dapat disimpulkan bahwa pengelolaan keuangan di Desa Ombulo Tango Kecamatan Tolangohula Kabupaten Gorontalo dapat dikatakan belum bisa 
sesuai dengan prinsip transparansi dan akuntabilitas.

\section{SARAN}

Saran yang dapat diberikan oleh peneliti adalah agar penerapan Transparansi dan juga akuntabilitas pengelolaan keuangan desa Ombulo Tango Kecamatan Tolangohula :

1. Pemerintah desa sendiri juga diharapkan lebih mampu lagi meningkatkan dan mendorong masyarakat agar lebih ikut serta dan berperan aktif untuk hadir dalam forum rapat musrenbang agar pemerintah dapat menerima setiap masukan-masukan dari masyarakat.

2. Pemerintah desa juga agar dapat memakasimalkan tentang bentuk transparansi dan akuntabilitas pengelolaan keuangan desa berdasarkan aturan yang ada, seperti melibatkan masyarakat dalam proses perencanaan pengelolaan keuangan desa, pemasangan papan informasi terkait anggaran, dan untuk pelaporan juga dibuatkan yang dapat diakses oleh seluruh pihak terkait termasuk masyarakat.

3. Ada baiknya Badan Pengawas Daerah melakukan pengawasan lebih Untuk menjaga stabilnya pengelolaan keuangan desa Ombulo Tango, sehingga dapat membuat pengelolaan keuangan desa yang transparan dan akuntabel.
4. Masyarakat agar dapat terus mengawal bagaimana untuk proses pengelolaan keuangan desa Ombulo Tango sendiri yang dilakukan oleh pemerintah desa berdasarkan aturan yang sudah ada, dan dapat menjalin kerja sama dengan pemerintah desa khususnya.

5. Bagi peneliti selanjutnya yang akan meneliti tentang bagaimana suatu proses transparansi dan proses akuntabilitas pengelolaan keuangan desa ini agar lebih mendalami kajian penelitiannya.

\section{Referensi}

Abdul Hafiz Tanjung. (2011). Akuntansi, Transparansi, dan Akuntabilitas Keuangan Publik (Sebuah Tantangan).

Halim, Abdul. (2014). Manajemen Keuangan Sektor Publik problematika penerimaan dan pengeluaran pemerintah. Jakarta : Selemba Empat

Hari Sabarno, Memandu Otonomi Daerah Menjaga Kesatuan Bangsa, Sinar Grafika Graha, Jakarta, 2008

Mardiasmo. (2009). Akuntansi Sektor Publik edisi kedua. Yogyakarta: Andi Yogyakarta.

Mahmudi. 2010. Manajemen Kinerja Sektor Publik. Jakarta. STIE YKPN

Rossa, Sunardi. 2019 Manajemen Alokasi Dana Desa dalam Upaya dan Strategi untuk dapat Mewujudkan Desa Sejahtera Mandiri di Desa Cihambulu, Kec. Pabuaran, Kab. Subang, Jawa Barat

Saryono (2010), Metode Penelitian Kualitatif. PT. Alfabeta : Bandung 
Sukrisno agoes dan i cenik ardana (2009) Agoes, Sukrisno, I Cenik Ardana. (2009). Etika Bisnis dan Profesi: Tantangan untuk Membangun Manusia Seutuhnya. Jakarta : Salemba Empat.

Sugiyono. (2011). Metode Penelitian Kualitatif, Kuantitatif dan R\&D. Bandung : Alfabeta

Undang-Undang Nomor 6 Tahun 2014 Tentang Desa, Lembaran Negara

Republik

Waluyo,(2017).Perpajakan Indonesia. Jakarta: Salemba Empat

Yulianti, Wiken. (2019). Analisis Transparansi dalam hal untuk Pengelolaan Anggaran dalam Pendapatan dan Belanja Desa di Desa Teluk Beringin Kecamatan Gunung Toar Kabupaten Kuantan Singingi

Lalolo Krina P. (2012). Indikator dan alat ukur akuntabilitas, sebagai bentuk transparasi dan juga partisipasi. Sekretaris Good Public Governance. Badan Perencanaan Pembangunan Nasional

Yulianti, Wiken. (2019). Analisis Transparansi pelaporan dalam Pengelolaan Anggaran desa Pendapatan dan Belanja Desa di Desa Teluk Beringin Kecamatan Gunung Toar Kabupaten Kuantan Singingi

Wahyu. (2018). Akuntabilitas dan Transparansi Pemerintah Desa dalam Pengelolaan Alokasi Dana Desa (ADD) di Desa Borong Pa'La'La Pattallassang Kabupaten Gowa.

Widiyanti,Arista.(2017). Akuntabilitas dan Transparansi Pengelolaan Alokasi Dana Desa (Studi pada Desa Sumberejo dan Desa Kandung di
Kecamatan Winongan Kabupaten Pasuruan)

Rossa, Sunardi. 2019 Manajemen Alokasi Dana Desa dalam rangka Upaya dan Strategi Mewujudkan Desa Sejahtera Mandiri di Desa Cihambulu, Kec. Pabuaran, Kab. Subang, Jawa Barat

Peraturan Menteri Dalam Negeri Nomor 113 Tahun 2014 menjelaskan tentang aturan Pengelolaan Keuangan Desa

Undang-Undang No. 14 tahun 2008 tentang Keterbukaan Informasi Publik. 